\title{
Lean implementation in a service factory: views from the front-line
}

\author{
Marisa Smitha ${ }^{a}$ Steve Paton ${ }^{a}$ and Jillian MacBryde \\ aDepartment of Strategy and Organisation, Strathclyde Business Schools, Glasgow, UK; \\ ${ }^{b}$ The York Management School, University of York, York, UK
}

\begin{abstract}
The deployment of Lean methods in service work is increasingly viewed as a legitimate response to the growing requirement for more efficient front-line service delivery. However, research investigating Lean implementations is reporting mixed results with process efficiency gains frequently marginalised by losses in employee satisfaction and customer focus. It has been suggested that these sub-optimal outcomes are the result of partial adoptions of Lean where the emphasis is placed on process efficiency with employee and customer outcomes neglected. Using an Action Research approach this paper investigates the outcomes of a Lean implementation within a UK call centre. The Action Research methodology used ensured that a holistic rather than a partial implementation of Lean was achieved and this research finds that Lean when implemented properly can lead to improved process efficiency, a better customer experience and increased employee satisfaction. It suggests that to achieve these optimum outcomes Lean implementations must as a priority be focused on creating customer satisfaction and be customised to fit with particular contingencies in the organisational context such as the nature of the interface between the front-line worker and the customer.
\end{abstract}

This is a peer-reviewed accepted author manuscript of the following research output: Smith, M., Paton, S., \& MacBryde, J. (2017 - online). Lean implementation in a service factory: views from the front-line. Production Planning and Control. DOI: 10.1080/09537287.2017.1418455 


\section{Introduction}

Since Bell (1973) wrote about the coming of the post-industrial society, the impact of this so-called 'new economy' (Webber, 1993) on workers and how they are managed has been widely debated. Three related aspects of this new economy are of interest here. First, the growth in service work and more specifically non-professional services delivered on a large scale within so-called service factories (Schmenner, 1986); second, the accompanying emergence of customer-centric control where bureaucratic control is joined, and often usurped, by customer normative control (Korzinski 2000); and third the emergence of employee-centred management where forced compliance is replaced by inspired commitment (Webber, 1993).

The service factory is usually typified by the contact centre (Russel, 2008). This increasingly common organisational form attempts to fit the information and people-centred, 'front-line' worker (Frenkel, 1999) into the contemporary embodiment of a scientifically managed (Taylor, 1911) work system (Taylor and Bain 1999). While it is clear that contact centres must provide consistent and efficient service delivered on a large scale it is also argued that, due to the customer-facing nature of the work, skill retention and worker empowerment is desirable (Glucksman, 2004; Taylor and Bain 2007).

Therefore the need to meet these 'dual logics of efficiency and customer orientation' (Korczynski et al, 2000:671) combined with the imperative to find a way to effectively manage the front-line worker in an employee-centric way result in a somewhat contested terrain (Edwards, 1979) where the tensions brought by these differing considerations must be resolved.

In tandem with this growth in service sector activity, Lean (Womack et al 1990) emerged from the manufacturing sector where companies that had adopted it reported achievement of improved process efficiency through reduced overall waste, increased customer focus and product quality and, most crucially, higher levels of worker satisfaction due to job enrichment and empowerment (de Treville and Antonakis, 2006).

Initially it seemed that the remedies that Lean promised fitted nicely as a cure for the maladies found in the service factory and this supposition resulted in the gradual adoption of Lean within service factories across many parts of the service sector (Ahlstrom, 2004). However research investigating these Lean implementations has reported mixed results. A common feature of this research is its identification of 'partial' implementations of Lean with deployment of process improvement toolsets and associated focus on the mechanics of the work system often prioritised over the adoption of the Lean philosophy in its entirety. This partial adoption, while bringing increased efficiency (Pavnaskar et al., 2003) generally leads to little change in the employee condition (Parker, 2003) and reduced 
customer focus has also been reported (Bamford et al., 2015). These findings have resulted in some scepticism about the overall utility of Lean when deployed within the service sector.

Here we propose that currently within service factories only a partial understanding of the effects of Lean exists, and this understanding is informed mainly by research on the application of the 'tools' of Lean rather than the deployment of the wider Lean 'philosophy'. The objective of this article is to address this gap by researching the adoption of Lean in a more holistic manner investigating the triple requirements of process efficiency, employee satisfaction and customer focus.

It will do this by reporting on the deployment of Lean within a large call centre within the Insurance sector of the Financial Services Industry. Crucially it must be noted that this research differs somewhat from previous work as it is action-oriented with researchers participating in the change process. This is significant as it provided the opportunity to avoid the issues of partiality present in previous implementations and enabled the research to contribute a more balanced view on Lean implementation.

This article is organised as follows. First, the existing literature on the adoption of Lean in service work and how it effects the condition of the worker employed within the contact centre is reviewed. Second, the findings of a longitudinal, mixed-methods case study describing Lean implementation within the contact centre are presented. Third, it discusses how these findings inform the debates on employee experience and customer focus. It then concludes by discussing the broader relevance of this research in relation to Lean in service work.

\section{Lean and the Service Sector}

Gaining widespread attention in the 1990s with the publication of The Machine that Changed the World (Womack et al., 1990), the rather sudden arrival of Lean led to the fairly fundamental misconception of it as a relatively recent product of the Japanisation narrative of the late 1970s. Though maturing as a volume production system in the 1980s, the origins of Lean can be traced to the late 1940's with materials management techniques such as Just-in-Time (JIT) (Schonberger, 1982) and Kanban (Kim, 1985) beginning to influence the way manufacturing in Japan was managed (Suzaki, 1985). Then, propelled over a number of years by a series of innovations, it evolved into what became known as the Toyota Production System (TPS) (Holweg, 2007).

Originally the TPS was born out of the Japanese' need to compete with western car manufacturers. Although influenced at its outset by western mass-production systems its evolution was very much shaped by the boundaries of the market, the economic constraints of the time and the very specific 
cultural characteristics of the available workforce. Initially in geographically-isolated Japan, Toyota only had access to smaller local markets and was therefore forced to create a more flexible manufacturing system to undertake the manufacture of smaller batches of easily configurable product to exploit all available niches. This was in contrast to the mass manufacturing focus of Western companies like Ford where access to more extensive markets allowed the production of large numbers of less differentiated products. In addition, Japanese post-war economic weakness encouraged efficiency by more effectively managing waste and engineering-in quality, again in contrast to Western method of 'inspecting-out' defects while accepting the associated rework cost.

Further, the Japanese system was built on an educated, loyal, workforce where workers were encouraged to 'display their capabilities to the utmost' (Sugimori et al., 1977: 554). Again in stark contrast to the Western system designed for an unskilled workforce with little company affiliation.

This resulted in a manufacturing system that was customer-focused and flexible and enabled by the adaptable worker. However, rather ironically, by the 1990s when Lean was being adopted more widely, Japanese manufacturers had outgrown their geographical and economic constraints and were engaging in high-volume manufacture which, to the uninitiated, looked substantively similar to Western mass manufacturing systems. As a result the true differences between the two systems were widely ignored and the subtleties of the TPS system were all-to-often lost (Mehri, 2006). Lean therefore very quickly became known as a form of mass manufacture when in fact it is aimed at fundamentally altering the "conventional logic of mass production" (Holweg 2007:422).

It would be incorrect to attribute all responsibility for this misconception to the globalisation of Japanese companies. Some blame can be placed on the original Womack et al. (1990) publication both in its adoption of the term Lean that suggests process efficiency, and in its use of less technical language. While making Lean accessible and portable across sectors it also resulted in the loss of critical methodological detail specifically the importance of marrying the mechanistic process improvement methods with the organic employee and customer management aspects. Interestingly, this marriage is rather neatly suggested in the first article published in English on the Toyota Production System (Sugimori et al., 1977) with the title describing a 'just-in-time' and 'respect-forhuman' system. Therefore Lean, as generally understood, is to a large extent a post-hoc rationalisation of a much more comprehensive and complex socio-technical system.

With Lean finding widespread application outside the manufacturing sector recent studies would seem to indicate that the service sector has become the new frontier for Lean deployment (Hadid and Mansouri, 2014; Antony et al., 2017). The Lean services literature is in consequence growing and 
evolving, moving from the exploration of the fit of Lean methodologies within service work to studies of its implementation in various service environments (Suárez-Barraza et al., 2012; Gupta et al., 2016). The result is a growing body of literature on Lean in sectors such as healthcare (Costa and Filho, 2016), IT (Kundu and Manohar, 2016), financial services (Leyer and Moormann, 2014), education (Balzer et al., 2015) and the public sector (Radnor and Osborne, 2013).

The application of Lean in the healthcare sector in many ways typifies the penetration of Lean into service work. Here it gained attention as a means to increase productivity by reducing hospital waste and increasing patient flow rates (Kollberg et al., 2006). The majority of studies were undertaken within the US where understandably there is much focus on productivity given the commercial nature of the US healthcare system (Toussaint and Berry, 2013; Dobrzykowski et al., 2016).

Lean in healthcare is also gaining attention in the UK with many studies analysing implementations in the NHS (Grove et al., 2010; Lindsay et al., 2016). The majority of these studies focus on success factors such as management support (e.g. Poksinska 2010), and barriers such as the widespread perception of Lean as only applicable to manufacturing (e.g. de Souza and Pidd, 2011) and opposition displayed by those involved (e.g. Davis and Adams, 2012). Further D'Andreamatteo et al's (2015) review of literature on Lean in healthcare reveals a lack of consideration of the 'system wide approach' to Lean implementation. It demonstrates that the majority of studies focus on the application of specific principles and tools to single processes or individual departments. Similarly, Costa and Filho (2016) in their review of Lean in healthcare found that Lean continues to be implemented in a superficial way, through the deployment of specific tools rather than the holistic adoption of all of its aspects.

Outside Healthcare, the situation is similar. For example, one Lean implementation in Her Majesty's Revenue and Customs (HMRC), a UK government department, has been scrutinized extensively and has stimulated much academic debate on the appropriateness of Lean in the public sector (Radnor and Boaden, 2008; Radnor and Johnston, 2013;). Interestingly this research resulted in different opinions on the success of the same Lean implementation. On one hand the implementation was found to increase productivity (Radnor et al., 2006) while on the other it was found to result in the deskilling of jobs and greater unhappiness in employees (Carter et al., 2011). Despite these contrasting views researchers were in broad agreement that the implementation of Lean in this organisation was characterised by narrow focus on the mechanistic deployment of process-based tools (Carter et al., 2017; Proctor and Radnor, 2017).

This narrow focus is reflected in other studies that show that many implementations are based on "...limited, piecemeal approaches-quick fixes to reduce lead time and costs" (Liker and Morgan, 
2006:5). It has therefore been suggested that Lean implementations within service environments are typified by a focus on process efficiency while showing little consideration for the wider effects on the services provided, the customer or the employees (McAdam et al., 2016). Although it could be concluded that this is an issue peculiar to the service industry, in their review of Lean implementation and performance Negrão et al. (2016) find that this partial implementation of Lean is also common in manufacturing organisations with Lean implemented in a fragmented way, disregarding the systemic linkages essential to wider success.

Ironically the nature of manufacturing work means that improvements in process efficiency are often enough to lay claim to the success of a Lean implementation. In contrast features unique to service work, particularly its intangibility and its customer-facing aspect (Lovelock and Gummesson, 2004) make process-based success less impactful. Concern over the effect of direct implementation of manufacturing methods into service environments is longstanding (Levitt, 1972) and tendencies to import directly with little consideration of service contingencies has persisted with some of the studies of Lean implementations in service contexts identifying a 'cut and paste' approach from manufacturing (Bowen and Youngdahl, 1998).

There is therefore a degree of confusion within the literature in relation to the efficacy of Lean within the service sector that seems to stem from a combination of the nature of service work and the nature of the implementation process. This research adopts the stance that currently only a partial understanding of Lean implementation within the service sector exists, and this understanding is informed mainly by research on the application of the 'tools of Lean' rather than the deployment of the wider Lean 'philosophy'.

The objective of this article is therefore to address this confusion by researching a Lean implementation that was carried out in a more holistic manner so enabling the simultaneous investigation of the triple requirements of process efficiency, employee focus and customer orientation.

\section{Research Approach}

To facilitate this research and in particular ensure a holistic Lean implementation an Action Research approach was adopted. Action Research allows participants to contribute to the design of the intervention (Coughlan and Coghlan, 2002; Burns et al., 2014), here it allowed the research team to be involved in the Lean implementation process, ensuring it was carried out correctly and then examine the impact the change had on the process, the employees and the customer. 
The case study company is an insurance intermediary called InsureCo (IC), operating in the UK insurance brokerage industry, the research was conducted over three years from 2008 to 2011. The data collection phase utilised a mixed methods approach. The primary method was participant observation with one member of the research team embedded within the company fully involved with the Lean implementation. This researcher participated in the majority of implementation meetings, presentations and training and awareness sessions held throughout the implementation period giving suggestions and guidance as to the changes to be made for the intervention. In addition, this researcher also undertook a call listening study aimed at understanding in more detail how the Lean implementation was being received on the 'shop-floor' of the contact centre, and engaged in a large number of informal conversations with agents during this time in an attempt to gain a clear understanding of how they individually viewed the change process. All observations were written up into a research journal. This approach to data collection is consistent with the action research methodology (Coughlan and Coghlan, 2002).

This data was supplemented by 30 semi-structured and unstructured interviews conducted with management, team leaders and agents. Consistent with Holstein and Gubrium's (1995) concept of the 'active interview', the semi-structured interviews set out to develop detailed accounts of actor's positions and understandings to facilitate joint construction of meaning, these interviews were not intended to extract information from a passive subject but rather to stimulate narrative production. Interviews followed a standard protocol generated by researchers, each of these interviews lasted between one and two hours and were digitally recorded, transcribed and anonymised. Data analysis was conducted using an inductive, iterative process whereby axial coding (to build categories to group coded data) and selective coding (to relate these categories to the core category or storyline) was conducted in sequence, before categories were examined for discursive coherence (Strauss and Corbin, 1998).

\section{The Case Study Company - IC Insurance}

IC provides insurance to the UK market for vehicles, homes, pets and travel. Their main operation is contained in a single contact centre located in the Central Belt of Scotland where it employs over 800 staff who handle around 10 million telephone calls per annum as well as e-mail and written correspondence from customers and other insurance companies.

This research focused on the implementation of Lean in the service department which is the largest sub-unit of the contact centre. This department is responsible for a variety of activities such as supplying new quotes, maintaining customers' details and dealing with other general queries. The 
contact centre environment has proved a useful context in which to examine different types of phenomenon and different typologies have been defined (see Batt and Moyinhan, 2002). The service department in IC can be classified as operating in the traditional mass production model that some suggest is the most common type of contact centre studied in the literature (Garson, 1988; Fernie and Metcalf, 1998; Taylor and Bain, 1999). This type of contact centre competes by offering an efficient, cost effective solution to handing large amounts of calls. The key performance objectives within this type of operation are therefore overall cost of operation, speed of service and volume of calls handled. This type of service operation tends to favour Taylorised working with repetitive tasks supported by automation and it can be compared to mass production factories where the focus is on high volume, low variety and efficiency.

In recent years insurance companies have been part of an evolving market and a feature of this evolution is the increased dominance of price aggregators (FSA, 2008). This is significant and essentially means that through a single website customers can more quickly search for the lowestpriced insurance policies and then more easily change policies. This market innovation has effectively removed cost as a differentiator. IC realised that these changes in the market meant that in order to retain customers (through year-on-year policy renewal) they needed to differentiate themselves from their competitors by improving customer service.

IC therefore decided to undertake a change programme facilitated by the deployment of Lean methodology. Lean was chosen primarily as it emphasises a focus on customer value and therefore one of the first steps taken by IC was to investigate what in the current operation caused customer dissatisfaction. The three main issues identified by customers were being passed between agetns (and departments), being placed on hold and call-handlers attempting to sell them additional products.

From this analysis new ways of interacting with the customer were developed. The core of this change was the introduction of a 'one-stop-shop' approach to customer service. To support this approach changes were needed in three areas.

First, in performance measurement where a First Call Resolution (FCR) target was introduced. The objective of this new measure was to change the focus of the call-handler from working to reduce calltimes to working to solve the customer's problems. Second, employee multiskilling was introduced to enable employees to discharge the wider scope of responsibility inherent in this new approach. Third the introduction of more streamlined processes to support agents in achieving quick and efficient resolution. 


\section{Lean Deployment - Findings}

Table 1 outlines the changes made by the Lean implementation in performance criteria and in process design.

Table 1 - Changes to performance criteria and process design

\begin{tabular}{|c|l|l|l|}
\cline { 2 - 4 } \multicolumn{1}{c|}{} & \multicolumn{1}{|c|}{ Before } & \multicolumn{1}{c|}{ After } & \multicolumn{1}{c|}{ Comments } \\
\hline $\begin{array}{c}\text { Performance } \\
\text { Criteria }\end{array}$ & $\begin{array}{l}\text { Primarily sales } \\
\text { focused }\end{array}$ & $\begin{array}{l}\text { Emphasis on customer } \\
\text { service metrics such as } \\
\text { first call resolution (FCR) } \\
\text { but some sales focus } \\
\text { remains. }\end{array}$ & $\begin{array}{l}\text { The focus shifted from targets and measures } \\
\text { which rewarded sales performance (often } \\
\text { resulting in dishonest behaviours) to one } \\
\text { focused on customer focused measures. }\end{array}$ \\
\hline $\begin{array}{c}\text { Process } \\
\text { Design }\end{array}$ & $\begin{array}{l}\text { Low levels of } \\
\text { customer satisfaction } \\
\text { with customers } \\
\text { feeling irritated or } \\
\text { dissatisfied with the } \\
\text { call }\end{array}$ & $\begin{array}{l}\text { Focus on customer } \\
\text { experience resulting in } \\
\text { higher levels of customer } \\
\text { satisfaction }\end{array}$ & $\begin{array}{l}\text { The main ethos of the initiative was to put the } \\
\text { customer at the heart of the operation. Higher } \\
\text { levels of customer satisfaction were witnessed } \\
\text { via a comparative external customer satisfaction } \\
\text { study. } \\
\text { Previously the agent and very little view of what } \\
\text { other processes were undertaken within the } \\
\text { contact centre and had no linkages between } \\
\text { them whereas the introduction of a more end- } \\
\text { to-end process thinking resulted in the agents } \\
\text { having a wider understanding of the customer } \\
\text { journey. }\end{array}$ \\
\hline
\end{tabular}

\section{Performance criteria}

The main focus of Lean was solving customers' problems during their first contact therefore avoiding multiple transfers between agents and the associated delay and increased opportunity for error. This in the Lean methodology represents a reduction in waste.

This was achieved through modification of the performance criteria, refocusing targets from sales and productivity to customer satisfaction embodied here in the FCR target. FCR essentially measures how many times the customer has to call back for the same problem and so indicates if their issue was resolved or was not resolved in a single attempt. To reinforce this change the bonus structure was modified so that employees were rewarded for FCR scores rather than sales performance. The implementation of the FCR measure also resulted in the contact centre agents being cross-trained in order to deal with any issue the customer may have.

Overall the FCR target was perceived by both agents and team leaders as a positive measure. The general feeling being that as a customer service area the emphasis should be less on sales and more on customer focus. One interviewee summarised the basic wisdom of this change by suggesting that: 
this measure is what we have been waiting for... we are a customer service area after all (Team Leader).

Another highlighted the attraction for agents of this measure by proposing that:

the FCR target is easier to achieve than some of the sales targets...I would prefer if that was all we were measured on (Agent).

To implement FCR an effective balance between detail division of task and broader skilling is required.

IC embraced multiskilling so cross-trained their agents to deal with a greater number of issues. An approach that is in contrast to the traditional contact centre operations where specialisation of agents is encouraged. Multi-skilling had benefits for both the customer and employees. As one interviewee noted:

I now feel like I can actually help the customer rather than just passing them onto another area, it gives me a great feeling of completion that I know what has happened to customer when they've hung up (Agent).

Another interviewee revealed the frustration generated by the constraints that the previous system imposed:

...before even although I could help them (customer) I would still need to pass them over...now I am trained I feel I can help the customer more... before you felt like you were dealing with other people's mistakes (Agent).

Under the previous system the agents were not trained in all aspects of the call centre's business and so the transfer of customers to another agent in another part of the contact centre was common practice. After the change, agents felt that they had much more ownership over the outcome of the call with all the attendant benefits such as the personal satisfaction that comes with a job well done and a sense of closure.

In addition employee self-esteem was positively impacted as one agent noted:

It used to be embarrassing having to say to the customer 'I don't know the answer to that, I'll have to transfer you'...now I just deal with everything (Agent).

The feelings of embarrassment and of being seen as unhelpful were reiterated by many agents as they often felt powerless to help the customer. Further benefits were found in the process of work as this interviewee claimed: 
Because we are doing FCR now, it means I'm not just changing addresses all day. I can be doing anything on any call now. It's just more interesting to deal with everything... (Agent).

The nature of the agent's role had altered with repetition replaced by some degree of variety. This resulted in employees feeling that they are doing something much more worthwhile than the short interval repetitive tasks they were used to.

Some of the agents also reported that they now considered themselves a problem-solver rather than simply a call handler as they were skilled and empowered to solve the customers' issues:

Before it was all about 'sell, sell, sell' even if the customer was just phoning up to change their car details, but now it is about solving their issue and you get rewarded for using your own initiative...I see myself as a problem solver now (Agent).

Some agents described why they had taken a position in IC, thinking it was a customer service role and were not prepared for the level of selling that they were required to do. This interviewee's comment is typical of that misunderstanding:

I was at the point where I was wanting to leave as I'm rubbish at selling things and hated the feeling of not getting a chance to catch a breath between calls as they were so short...the calls are much longer now and you get time to work on the customers notes... ... so there is more time to get things done (Agent).

\section{Process Design}

To support the revised mode of operation some process redesign was undertaken. Customer surveys, focus groups and call listening studies were undertaken by the Lean implementation team as a starting point to understand why customers were dissatisfied with the service. Customers complained of problems in reaching an agent and this complaint resulted in the Interactive Voice Response (IVR) system being completely redesigned, with, for example, the number of choices being reduced. Customers also complained of excessive time spent on hold, on investigation it was concluded that this was an agent behaviour issue so agents were retrained.

With this more customer-centric approach to process design the role of the employee changed from simply 'servicing' the customer and passing them on, to being an advocate for the customer. Further employee involvement in the continuous improvement work inherent in the Lean methodology resulted in them feeling empowered to act on the behalf of the customer. Employees were also motivated by being a key part of the Lean implementation. This new culture is described by this interviewee: 
The main culture change is that we no longer implement any change without first creating a process map and initiating a project group of stakeholders. Changes are more structured and are definitely now being implemented based on data and agent experience rather than on gut instinct (Process Improvement Manager).

As part of the change, agents were given the opportunity to get real hands-on experience in working with the process improvement team by participating in workshops and focus groups. This again led to a change in culture as explained by this interviewee:

It is now more acceptable to be interested in improving your job, either for yourself or for the customer... we now feel that something will be done about our issues and suggestions (Agent).

This suggests that the introduction of Lean, and especially the continuous improvement aspect, resulted in a more inclusive environment with agents able to put their ideas forward confident that they will be taken seriously.

As Lean became increasingly embedded in the culture of IC more visible evidence of employee involvement began to appear. Large screens were setup in the contact centre to display each idea that an employee put forward, how it was implemented and what improvements resulted. The agents were also given a small reward if their idea was implemented. This interviewee outlines the impact of this initiative:

I loved seeing my picture and name up on the big screen next to what I had contributed...that was much better than the voucher I got as a prize for my idea... my idea was just something that was bugging me in my job so I'm happy that it is fixed...lots of people have been congratulating me (Agent).

Interestingly this suggests that agents are happier with their ideas being recognised, and with the consequent improvement in the contact centre, than the small reward.

The new process view of service that Lean brought allowed agents to become more aware of what happens 'upstream' and 'downstream' from their own area of the contact centre. The process approach broke boundaries that were traditionally present between departments. Previously many of the agents were unaware of the customer journey in other parts of the operation and the Lean focus on understanding the value stream helped to facilitate a boundary-spanning approach. This interviewee highlights the benefits of a more integrated system:

Before we did process mapping, the management would make changes to other areas of the business that would have a negative effect on the service area, for example changing their 
marketing material and not letting anyone from service know which meant that calls increased and agents did not know what the customers were talking about. This has all changed now and we now discuss and map how changes will affect the customer as well as our own internal processes (Process Improvement Manager).

This contrasts with the fragmented nature of the previous system as illustrated in the following quote:

"To be honest I have worked here for many years and I really wasn't sure about what happens in other areas of the call centre or what happened when I transferred a customer...due to the process mapping exercise we did I now have a much better idea of how we all fit together" (Agent).

The implementation of Lean ultimately resulted in some fundamental shifts in the role of employees and the nature of their tasks, these effects are highlighted in Table 2.

Table 2 - changes to employee role and nature of work

\begin{tabular}{|c|c|c|c|c|}
\hline & \multicolumn{2}{|c|}{ Employee Role } & \multicolumn{2}{|c|}{ Nature of Work } \\
\hline & Before & After & Before & After \\
\hline $\begin{array}{l}\text { Performance } \\
\text { Criteria }\end{array}$ & $\begin{array}{l}\text { Call Duration } \\
\text { Sales achieved }\end{array}$ & First call resolution & $\begin{array}{l}\text { Narrow - task focused } \\
\text { Single skilled } \\
\text { Volume and throughput } \\
\text { Repetitive }\end{array}$ & $\begin{array}{l}\text { Enlarged - customer focused } \\
\text { Multi-skilling } \\
\text { Quality } \\
\text { Varied }\end{array}$ \\
\hline $\begin{array}{l}\text { Process } \\
\text { Design }\end{array}$ & Task Based & Solution based & $\begin{array}{l}\text { Fragmented } \\
\text { Department focused }\end{array}$ & $\begin{array}{l}\text { Integrated } \\
\text { Customer focused }\end{array}$ \\
\hline
\end{tabular}

\section{Discussion}

In analysing these findings it is immediately obvious that two overarching points are worth noting. First, this particular Lean implementation was most concerned with enhancing the customer experience and placed less emphasis on the typical cost reduction objectives that typify many Lean implementations. Second, front-line workers (agents and team leaders) were included in the Lean implementation team as they were seen as crucial to the redesign of the processes and this involvement may explain why the employees felt more engaged in the implementation process. In some cases this might be construed as a cynical attempt by management to gain buy-in to the change but here the ethos of co-construction between management, front line workers, the in-company Lean 
implementation team and the academic research team led to a much more authentic initiative. While rather intangible in nature it is difficult to argue that these points are totally separate from the more tangible artefacts of this implementation.

It is clear that the form of the operational processes prior to the change seems to have some bearing on the outcome of the Lean implementation. This investigation found that the operational processes prior to the implementation were often fragmented featuring tasks that were short in duration and repetitive in nature. Customer-facing workers were focused on achieving throughput, in effect passing customers on to different areas of the contact centre, with very limited understanding of what happened in the overall customer journey. This resulted in employees with limited knowledge of the overall process who occupied routine and often monotonous jobs. After the implementation of Lean, the redesign of the processes resulted in workers with a wider understanding of the customer journey and jobs that were enlarged to deal with the end-to-end customer experience. Workers now feel that they are an advocate for the customer and have some control over the experience that the customer receives.

Therefore here the implementation of Lean had a positive impact enlarging the job of the front-line workers by redesigning the process and combining the previously fragmented tasks. This outcome seems to be in contrast to the findings of other studies of Lean implementations in services (e.g. Carter et al., 2011) where existing coherent end-to-end processes were split-up in attempts to achieve efficiency by division of labour.

Further, the shift in the focus of the performance measurement system has resulted in less time pressure placed on the customer-facing workers. This is surprising as performance measurement in the call centre context is often associated with the negative effects it has on workers such as increasing intensity and stress leading to job burnout (Kinnie et al., 2000; Wood et al., 2006). The positive impact FCR has had on customer-facing workers in this case is perhaps due to the removal of the dissonance previously felt as a result of the imposed time and sales targets that were often detrimental to the customer service experience. There was widespread enthusiasm about the FCR measure as it prioritised customer service while enriching the process of work for front-line staff who are now able to take the customer through to the full resolution of their issue. Prior to the Lean implementation agents often felt powerless to help the customer because of their limited knowledge. The FCR measure and multiskilling required to support it, perhaps more than any other element of the implementation, was perceived as a clear message that the focus was no longer on productivity but on the experience of the customer. 
The combination of revised performance measurement and redesigned process has resulted in the employees now acting as an advocate of the customer and a problem solver rather than simply a call handler.

In addition to the tangibles of process and performance measurement, it is worth returning to the intangibles mentioned briefly at the beginning of this section. This Lean implementation did place more emphasis on the Lean philosophy, again possibly enabled by the Action Research approach and the involvement of the research team. Here the 'respect-for-human' elements were strongly enforced through such things as the inclusion of employees in the Lean implementation and the consideration of the role of employees within the revised operation. As a result of participation in the implementation many of the employees reported that they felt more interested in their jobs and were more motivated to engage in further improvement work as they had a platform to propose ideas and also felt valued for their experience.

The act of participation itself seems to have alleviated some of the pressures inherent in contact centre work. Involvement in project work such as a Lean implementation provides the opportunity to widen the scope of an employee's activity and so enrich the process of work. Alder (2007) describes this as an enabling form of bureaucratic structure, where the underlying form of work is similar but the structure now allows for a more democratic approach to improvement.

\section{Conclusion}

This research explores the impact of Lean on work organisation within a service factory by implementing an Action Research approach within a contact centre in the Insurance Services industry.

Broadly the findings from this research indicate that Lean when applied in service work does not have to be synonymous with untrammelled Taylorism as proposed by other previous studies (Carter et al., 2011), but that a more nuanced situation exists with the success or failure of the implementation dependant on contingencies within the implementation.

First, in front-line work within a service factory it has been common to start with process efficiency as the first priority. This research has shown that the focus of the Lean implementation must be customised for the type of work and suggests that the quality of service from a customer perspective, embodied here as a seamless and effective service, is the most important consideration.

Second, in front-line service work within a service factory it has also been common to assume that division of labour leads to a better outcome. This research refutes this assumption as it has shown that the fit of the front-line worker within the operational process is more important than simply the 
shape of the process. It has demonstrated that the key factor driving the quality of the customer experience is the quality of the interface between the front-line worker and the customer. Here quality of service is embodied in an employee who is able to take the customer through the entire journey.

This research suggests that even in mass service work there is a clear link between the role of the employee and the satisfaction of the customer. Due to this link, process efficiency must come as a consequence of focusing on improving the customer experience rather than improved customer experience coming a consequence of a focus on simple process efficiency. Therefore this research to some extent contradicts previous work and suggests that the reconciliation of the dual logics of efficiency and customer orientation (Korczynski et al, 2000) can be achieved by intelligent pursuit of Lean where improved process efficiency and increased employee satisfaction can be achieved by focusing on enhancing the customer experience.

In summary the contribution of this research is twofold. First it provides evidence that Lean can be made useful in the pursuit of improved operational performance within service factories. But second, and most crucially, it suggests that a contingency approach must be adopted where the context is taken into consideration when designing and deploying the Lean implementation. Here consideration of the context resulted in the adoption of a particular approach where overall efficiency gains were the result of a focus on customer value and prioritisation of the interface between the front-line worker and the customer.

In consequence this research proposes that there currently exists only a partial understanding of the consequences of Lean implementations within the service sector. This understanding is dominated by research on the application of process improvement tools rather than the intelligent deployment of the holistic Lean philosophy. It suggests that future studies in Lean must be more nuanced, sensitive to the contingencies within the context and able to distinguish between outcomes that result from the way that Lean is implemented within a specific organisation and outcomes that result from the nature of the Lean philosophy.

\section{References}

Adler, P. S., Warhurst, C., Grugulis, I., \& Keep, E. (2004). Skill trends under capitalism and the socialisation of production. The skills that matter, 242-260.

Ahlstrom, P. (2004). Lean service operations: translating lean production principles to service operations. International Journal of Services Technology and Management, 5(5-6), 545-564.

Antony, J., Rodgers, B., \& Cudney, E. A. (2017). Lean Six Sigma in policing services: case examples, lessons learnt and directions for future research. Total Quality Management \& Business Excellence, 1-13. 
Balzer, W. K., Brodke, M. H., \& Thomas Kizhakethalackal, E. (2015). Lean higher education: successes, challenges, and realizing potential. International Journal of Quality \& Reliability Management, 32(9), 924-933.

Bamford, D., Forrester, P., Dehe, B., \& Leese, R. G. (2015). Partial and iterative Lean implementation: two case studies. International Journal of Operations \& Production Management, 35(5), 702727.

Batt, R., \& Moynihan, L. (2002). The viability of alternative call centre production models. Human Resource Management Journal, 12(4), 14-34.

Bell, D. (1973). The Coming of Post-Industrial Society. London Heinemann.

Bowen, D. E., \& Youngdahl, W. E. (1998). "Lean" service: in defense of a production-line approach. International journal of service industry management, 9(3), 207-225.

Burns, D., Hyde, P., Killett, A., Poland, F., \& Gray, R. (2014). Participatory organizational research: Examining voice in the co-production of knowledge. British Journal of Management, 25(1), 133-144.

Carter, B., Danford, A., Howcroft, D., Richardson, H., Smith, A., \& Taylor, P. (2011). 'All they lack is a chain': lean and the new performance management in the British civil service. New Technology, Work and Employment, 26(2), 83-97.

Carter, B., Danford, A., Howcroft, D., Richardson, H., Smith, A., \& Taylor, P. (2017). Uncomfortable truths - teamworking under lean in the UK. The international journal of human resource management, 28(3), 449-467. doi:10.1080/09585192.2015.1111251

Costa, L. B. M., \& Godinho Filho, M. (2016). Lean healthcare: review, classification and analysis of literature. Production Planning \& Control, 27(10), 823-836.

Coughlan, P., \& Coghlan, D. (2002). Action research for operations management. International Journal of Operations \& Production Management, 22(2), 220-240.

D’Andreamatteo, A., lanni, L., Lega, F., \& Sargiacomo, M. (2015). Lean in healthcare: a comprehensive review. Health Policy, 119(9), 1197-1209.

Davis, J., \& Adams, J. (2012). The 'releasing time to care-the productive ward'programme: participants' perspectives. Journal of Nursing Management, 20(3), 354-360.

de Souza, L. B., \& Pidd, M. (2011). Exploring the barriers to lean health care implementation. Public Money \& Management, 31(1), 59-66.

De Treville, S., \& Antonakis, J. (2006). Could lean production job design be intrinsically motivating? Contextual, configurational, and levels-of-analysis issues. Journal of Operations Management, 24(2), 99-123.

Dobrzykowski, D. D., McFadden, K. L., \& Vonderembse, M. A. (2016). Examining pathways to safety and financial performance in hospitals: A study of lean in professional service operations. Journal of Operations Management, 42, 39-51.

Edwards, R. (1979). Contested terrain: The transformation of the workplace in the 20th century. Heinmann, London.

Fernie, S., \& Metcalf, D. (1998). (Not) hanging on the telephone: payment systems in the new sweatshops: Centre for Economic Performance, London School of Economics and Political Science.

Frenkel, S. (1999). On the front line: Organization of work in the information economy: Cornell University Press.

FSA. (2008). Examples of good and poor practice in general insurance comparison websites. Retrieved from London:

Garson, B. (1988). The Electronic Sweatshop: How Computers are Transforming the Office of the Future into the Factory of the Past. New York: Simon and Schuster.

Glucksmann, M. A. (2004). Call configurations: varieties of call centre and divisions of labour. Work, employment and society, 18(4), 795-811.

Grove, A. L., Meredith, J. O., Macintyre, M., Angelis, J., \& Neailey, K. (2010). UK health visiting: challenges faced during lean implementation. Leadership in Health Services, 23(3), 204-218. 
Gupta, S., Sharma, M., \& Sunder M, V. (2016). Lean services: a systematic review. International Journal of Productivity and Performance Management, 65(8), 1025-1056.

Hadid, W., \& Afshin Mansouri, S. (2014). The lean-performance relationship in services: a theoretical model. International Journal of Operations \& Production Management, 34(6), 750-785.

Holstein, J. A., \& Gubrium, J. F. (1995). The active interview (Vol. 37): Sage.

Holweg, M. (2007). The genealogy of lean production. Journal of Operations Management, 25(2), 420437.

Kim, T.-M. (1985). Just-in-time manufacturing system: a periodic pull system. International Journal of Production Research, 23(3), 553-562.

Kinnie, N., Hutchinson, S., \& Purcell, J. (2000). 'Fun and surveillance': the paradox of high commitment management in call centres. International Journal of Human Resource Management, 11(5), 967-985.

Kollberg, B., Dahlgaard, J. J., \& Brehmer, P.-O. (2006). Measuring lean initiatives in health care services: issues and findings. International Journal of Productivity and Performance Management, 56(1), 7-24.

Korczynski, M., Shire, K., Frenkel, S., \& Tam, M. (2000). Service work in consumer capitalism: customers, control and contradictions. Work, Employment \& Society, 14(4), 669-687.

Kundu, G. K., \& Manohar, M. (2016). Prioritizing lean practices for implementation in IT support services. VINE Journal of Information and Knowledge Management Systems, 46(1), 104-122.

Levitt, T. (1972). Production-line approach to service. Harvard business review, 50(5), 41-52.

Leyer, M., \& Moormann, J. (2014). How lean are financial service companies really? Empirical evidence from a large scale study in Germany. International Journal of Operations \& Production Management, 34(11), 1366-1388.

Liker, J. K., \& Morgan, J. M. (2006). The Toyota way in services: the case of lean product development. The Academy of Management Perspectives, 20(2), 5-20.

Lindsay, C., Commander, J., Findlay, P., Bennie, M., Dunlop Corcoran, E., \& Van Der Meer, R. (2014). 'Lean', new technologies and employment in public health services: employees' experiences in the National Health Service. The international journal of human resource management, 25(21), 2941-2956.

Lovelock, C., \& Gummesson, E. (2004). Whither services marketing? In search of a new paradigm and fresh perspectives. Journal of service research, 7(1), 20-41.

McAdam, R., Galbraith, B., Miller, K., Moffett, S., \& McAdam, M. (2016). The role of Lean at the interface with between operations management and applied services within a large aerospace organisation: a boundary spanning perspective. Production Planning \& Control, 27(15), 12981311. doi:10.1080/09537287.2016.1221158

Mehri, D. (2006). The darker side of lean: An insider's perspective on the realities of the Toyota production system. The Academy of Management Perspectives, 20(2), 21-42.

Negrão, L. L. L., Godinho Filho, M., \& Marodin, G. (2017). Lean practices and their effect on performance: a literature review. Production Planning \& Control, 28(1), 33-56. doi:10.1080/09537287.2016.1231853

Parker, S. K. (2003). Longitudinal effects of lean production on employee outcomes and the mediating role of work characteristics. Journal of applied psychology, 88(4), 620.

Pavnaskar, S., Gershenson, J., \& Jambekar, A. (2003). Classification scheme for lean manufacturing tools. International Journal of Production Research, 41(13), 3075-3090.

Poksinska, B. (2010). The current state of Lean implementation in health care: literature review. Quality Management in Healthcare, 19(4), 319-329.

Procter, S., \& Radnor, Z. (2017). Teamworking and Lean revisited: a reply to Carter et al. The international journal of human resource management, 28(3), 468-480.

Radnor, Z., \& Boaden, R. (2008). Editorial: Lean in Public Services-Panacea or Paradox? Public Money \& Management, 28(1), 3-7. 
Radnor, Z., \& Johnston, R. (2013). Lean in UK Government: internal efficiency or customer service? Production Planning \& Control, 24(10-11), 903-915.

Radnor, Z., \& Osborne, S. P. (2013). Lean: a failed theory for public services? Public Management Review, 15(2), 265-287.

Radnor, Z., Walley, P., Stephens, A. and Bucci, G. . (2006). Evaluation of the Lean Approach to Business Management and its Use in the Public Sector. Retrieved from Edinburgh:

Russell, B. (2008). Call centres: A decade of research. International journal of management reviews, 10(3), 195-219.

Schonberger, R. J. (1982). Some observations on the advantages and implementation issues of justin-time production systems. Journal of Operations Management, 3(1), 1-11.

Schmenner, R. W. (1986). How can service businesses survive and prosper? Sloan management review(27), 21-32.

Strauss, A., \& Corbin, J. (1998). Basics of qualitative research techniques: Sage publications.

Suárez-Barraza, M. F., Smith, T., \& Dahlgaard-Park, S. M. (2012). Lean Service: A literature analysis and classification. Total Quality Management \& Business Excellence, 23(3-4), 359-380.

Sugimori, Y., Kusunoki, K., Cho, F., \& Uchikawa, S. (1977). Toyota production system and kanban system materialization of just-in-time and respect-for-human system. The International Journal of Production Research, 15(6), 553-564.

Suzaki, K. (1985). Japanese manufacturing techniques: their importance to US manufacturers. Journal of Business Strategy, 5(3), 10-19.

Taylor, F. (1911). The principles of scientific management. USA: Harper\& Brothers.

Taylor, P., \& Bain, P. (1999). 'An assembly line in the head': work and employee relations in the call centre. Industrial Relations Journal, 30(2), 101-117.

Taylor, P., \& Bain, P. (2007). Reflections on the call centre-a reply to Glucksmann. Work, Employment \& Society, 21(2), 349-362.

Toussaint, J. S., \& Berry, L. L. (2013). The promise of Lean in health care. Paper presented at the Mayo Clinic Proceedings.

Webber, A. M. (1993). What's so new about the new economy? Harvard business review, 71, 24-24.

Womack, J. P., Jones, D. T., \& Roos, D. (1990). Machine that changed the world: Simon and Schuster.

Wood, S., Holman, D., \& Stride, C. (2006). Human resource management and performance in UK call centres. British Journal of Industrial Relations, 44(1), 99-124. 